\section{Physiological Responses of Two Cool-season Grass Species to Trinexapac-ethyl under Traffic Stress}

\author{
Mohamad Hossein Sheikh Mohamadi, Nematollah Etemadi', \\ and Ali Nikbakht \\ Department of Horticulture, College of Agriculture, Isfahan University of \\ Technology, 8415683111 Isfahan, Iran
}

\section{Mohammad Pessarakli \\ School of Plant Sciences, The University of Arizona, Tucson, AZ 85721}

Additional index words. antioxidants activity, tall fescue, turfgrass, trinexapac-ethyl, traffic stress, wheatgrass

\begin{abstract}
Traffic stress is one of the major abiotic stresses that limits grass growth in lawn fields. The severity of losses depends on several factors, including the number of events per season, the athletic field size, and the soil moisture content during the traffic incident. Trinexapac-ethyl (TE) is considered to influence plant tolerance to traffic stress. Therefore, the physiological responses of the wheatgrass (Agropyron desertorum $L_{\text {.) }}$ ) and tall fescue (Festuca arundinacea $\mathrm{L}$. cv. Rebel) species to different levels of TE and traffic stress were investigated. A factorial experiment including combination of TE application and traffic stress treatments was performed based on a randomized complete block design (RCBD) with three replications in 2014 and 2015 . The treatments, including traffic stress (traffic and nontraffic stress) and TE at three levels $\left(0,0.25\right.$, and $\left.0.5 \mathrm{~kg} \cdot \mathrm{ha}^{-1}\right)$, were applied once every 3 weeks. The simulated traffic stress was imposed using a Brinkman traffic simulator (BTS). The results showed that traffic stress reduced the turf quality, relative water content (RWC), total chlorophyll content, and antioxidant activity and increased electrolyte leakage (EL), soluble sugar content (SSC), and malondialdehyde (MDA) in both species. Conversely, TE increased the turf quality, RWC, SSC, and total chlorophyll and resulted in less EL and MDA in both species. Furthermore, TE application increased the superoxide dismutase (SOD) (EC 1.15.1.1), ascorbate peroxidase (APX) (EC 1.11.1.11), and peroxidase (POD) (EC 1.111.1.7) activities, especially under traffic stress conditions. TE application enhanced the resistance to traffic stress in both species by improving the osmotic adjustment and antioxidant activity.
\end{abstract}

Turfgrass traffic is defined as injury to a turfgrass caused by direct pressure, tearing, and scuffing on the tissues, which crushes the leaves, stems, and crowns in concentrated traffic areas (Beard, 2005). Wear injury is evidenced by turfgrass discoloration and bare areas (Williams et al., 2010). Traffic stress is the most common and destructive abiotic stress for recreational and sports lawns (Minner and Valverde, 2005). Various methods can increase the wear tolerance of turfgrass. Several studies have reported the use of higher wear-tolerant species and the application of plant growth regulators as important methods to reduce traffic stress (Samaranayake et al., 2008; Williams et al., 2010). Among coolseason species, tall fescues are considered to have relatively good traffic tolerance (Minner and Valverde, 2005). However, previous studies have not reviewed responses of wheatgrass to traffic stress.

Trinexapac-ethyl is a plant growth regulator used on turfgrass that effectively reduces grass leaf growth and subsequent mowing

Received for publication 18 Aug. 2016. Accepted for publication 24 Oct. 2016.

${ }^{1}$ Corresponding author. E-mail: etemadin@cc.iut.ac.ir. requirement. TE is a gibberellic acid (GA) inhibitor that suppresses laminar cell elongation by inhibiting the 3 - $\beta$-hydroxylase conversion of GA-20 to the physiologically active $\mathrm{GA}_{1}$ (Adams et al., 1992). TE has been widely applied to increase the chlorophyll content, turf quality, and turf density, whereas reducing the shoot extension rate of several turfgrass species (Ervin and Koski, 2001; McCullough et al., 2006; Pannacci et al., 2004).

The abovementioned impacts of TE can affect turfgrass tolerance to different stress such as traffic conditions. Williams et al. (2010) demonstrated that TE application improved the turf quality of bermudagrass under simulated traffic conditions. Also, Brosnan et al. (2010) reported that TE application improved resistance to traffic stress in bermudagrass (Cynodon dactylon L.). The beneficial effects of TE application for improving turf quality under stress conditions other than traffic have been also evaluated. For instance, Bian et al. (2009) reported that TE application effectively influenced turf growth during drought stress by reducing water use and improving osmotic adjustment. Also, TE has been shown to increase salinity tolerance of bermudagrass (Baldwin et al., 2006), shade tolerance, and combined drought and heat tolerance of creeping bentgrass
(Agrostis stolonifera L.) (Goss et al., 2002; McCann and Huang, 2007).

Although TE is being used widely in turfgrass management and evidence supports that TE application may promote the wear tolerance of turfgrasses (Michael and Williams, 2010; Williams et al., 2010), the physiological method by which TE may regulate turfgrass responses to traffic stress is not well documented. This study was conducted to determine the physiological responses of wheatgrass and tall fescue species to different levels of TE and traffic stress.

\section{Materials and Methods}

Plant materials and growth conditions. This study was conducted during two growing seasons (2014 and 2015) in the Department of Horticulture at Isfahan University of Technology, Isfahan, Iran, under field conditions. A loamy-clay soil with good drainage, $\mathrm{pH}$ of 7.43 and containing $0.6 \%$ organic matter were used. The plots were fumigated with methyl bromide before trial establishment to eliminate competition from weeds. The plots were seeded on 21 Sept. 2014 and 27 Sept. 2015. Seeds of tall fescue (F. arundinacea cv. Rebel) and native wheatgrass (Agropyron desertorum L.), which were collected from the turfgrass research farm at Fereydan, Isfahan, were hand broadcast and cultivated in plots $(6 \times 4 \mathrm{~m})$ at seeding rates of $25 \mathrm{~g} \cdot \mathrm{m}^{-2}$ (tall fescue) and $30 \mathrm{~g} \cdot \mathrm{m}^{-2}$ (wheatgrass). The plots were irrigated $(\mathrm{pH} \mathrm{7.1}$, electrical conductivity $0.4 \mathrm{mS} \cdot \mathrm{cm}^{-1}$ ) to maintain the soil humidity content at $80 \%$ field capacity or higher to avoid any visible drought stress during plant establishment. Fungicides were applied as a curative control for the summer patch and dollar spot on wheatgrass and tall fescue. A $10-5-10\left(\mathrm{~N}-\mathrm{P}_{2}\right.$ $\mathrm{O}_{5}-\mathrm{K}_{2} \mathrm{O}$ ) fertilizer was applied at $15 \mathrm{~g} \cdot \mathrm{m}^{-2}$ once every 2 weeks beginning at seeding and once per month from October to June. Wheatgrass and tall fescue were maintained at a cutting height of $4 \mathrm{~cm}$ and were mowed when needed using a reel-type mower.

Treatments. A factorial experiment including combination of TE application and traffic stress treatments was performed based on an RCBD with three replications. TE (Primo Maxx; Syngenta Crop Protection, Inc., Greensboro, NC) was applied to plots at three concentrations $\left(0,0.25\right.$, and $\left.0.5 \mathrm{~kg} \cdot \mathrm{ha}^{-1}\right)$. TE was

Table 1 . Turf quality (visually rated on the scale of $1-9$, with 9 being the best) affected by traffic stress and TE for wheatgrass and tall fescue.

\begin{tabular}{lcll}
\hline Grass & TE & Traffic & No traffic \\
\hline Wheatgrass & No TE & $6.6 \mathrm{~d}^{\mathrm{z}}$ & $7.3 \mathrm{bc}$ \\
& TE 0.25 & $7.19 \mathrm{~cd}$ & $7.89 \mathrm{ab}$ \\
& TE 0.5 & $7.55 \mathrm{abc}$ & $8.07 \mathrm{a}$ \\
Tall fescue & LSD $(0.05)$ & 0.69 & 0.69 \\
& No TE & $7.07 \mathrm{~d}$ & $7.92 \mathrm{bc}$ \\
& TE 0.25 & $7.62 \mathrm{c}$ & $8.14 \mathrm{ab}$ \\
& TE 0.5 & $7.8 \mathrm{c}$ & $8.35 \mathrm{a}$ \\
& LSD $(0.05)$ & 0.72 & 0.72 \\
\hline
\end{tabular}

$\mathrm{TE}=$ trinexapac-ethyl $\mathrm{LSD}=$ least significant difference. ${ }^{\mathrm{z}}$ For each species, means within a column followed by the same letters are not significantly different based on the LSD test at $P=0.05$. 
applied at 3-week intervals throughout the growing season beginning for two cool-season grass species. The TE was applied using a $\mathrm{CO}_{2}$-pressurised backpack sprayer (35 psi) equipped with an 8002VS nozzle (Spraying Systems Co., Wheaton, IL). The spray solution was applied at a volume of $0.2 \mathrm{~L} \cdot \mathrm{m}^{-2}$. In addition, control plants were sprayed with $0.2 \mathrm{~L} \cdot \mathrm{m}^{-2}$ clear water. The simulated traffic stress was imposed using a BTS (Cockerham and Brinkman, 1989) three times per week, including each Saturday, Monday, and Thursday, regardless of the soil moisture status or weather condition. This traffic system is roughly equivalent to turf injure from three American football games per week (Williams et al., 2010).

Measurements. Collecting leaf samples from each plot started on day 0 followed by days 21,42 , and 63 after the beginning of the traffic treatment to determine their RWC, chlorophyll concentration, EL, proline content, MDA content, SSC content, CAT (EC 1.111.1.6) activity, SOD (EC 1.15.1.1) activity, APX (EC 1.11.1.11) activity, and POD (EC 1.111.1.7) activity.

Turf quality. The turf quality was visually rated on a scale of 1 to 9 (National Turfgrass Evaluation Program) based on the color, density, and uniformity (Beard, 2005). Plants rated 1 were completely dead with a completely necrotic turf canopy. A rating of 9 represented healthy plants with dark green, turgid leaf blades, full turf canopy and dense turf.

Relative water content. Randomly sampled leaves $(200 \mathrm{mg})$ were taken from each plot, weighed [fresh weight (FW)], and placed in a petri dish filled with distilled deionized water for $24 \mathrm{~h}$. The leaves were then weighed [turgor weight or saturated weight (TW)] after removing surface moisture on the leaf with tissue paper. The leaves were then dried at $80^{\circ} \mathrm{C}$ for $48 \mathrm{~h}$ and weighed [dry weight (DW)]. The leaf RWC was calculated as follows: (FW $\mathrm{DW}) /(\mathrm{TW}-\mathrm{DW}) \times 100$ (Barrs and Weatherley, 1962).

Cell membrane stability (determined as EL). The amount of $0.3 \mathrm{~g}$ fresh leaf was placed in an experiment tube containing $30 \mathrm{~mL}$ of distilled deionized water for $4 \mathrm{~h}$. The tubes were shaken for $24 \mathrm{~h}$ and the first conductance (Ci) was calculated with a conductivity meter (YSI-3100; Guangzhou, China). The leaf samples were then killed at $120^{\circ} \mathrm{C}$ for $30 \mathrm{~min}$, and the maximal conductance of the dead tissue (Cmax) was

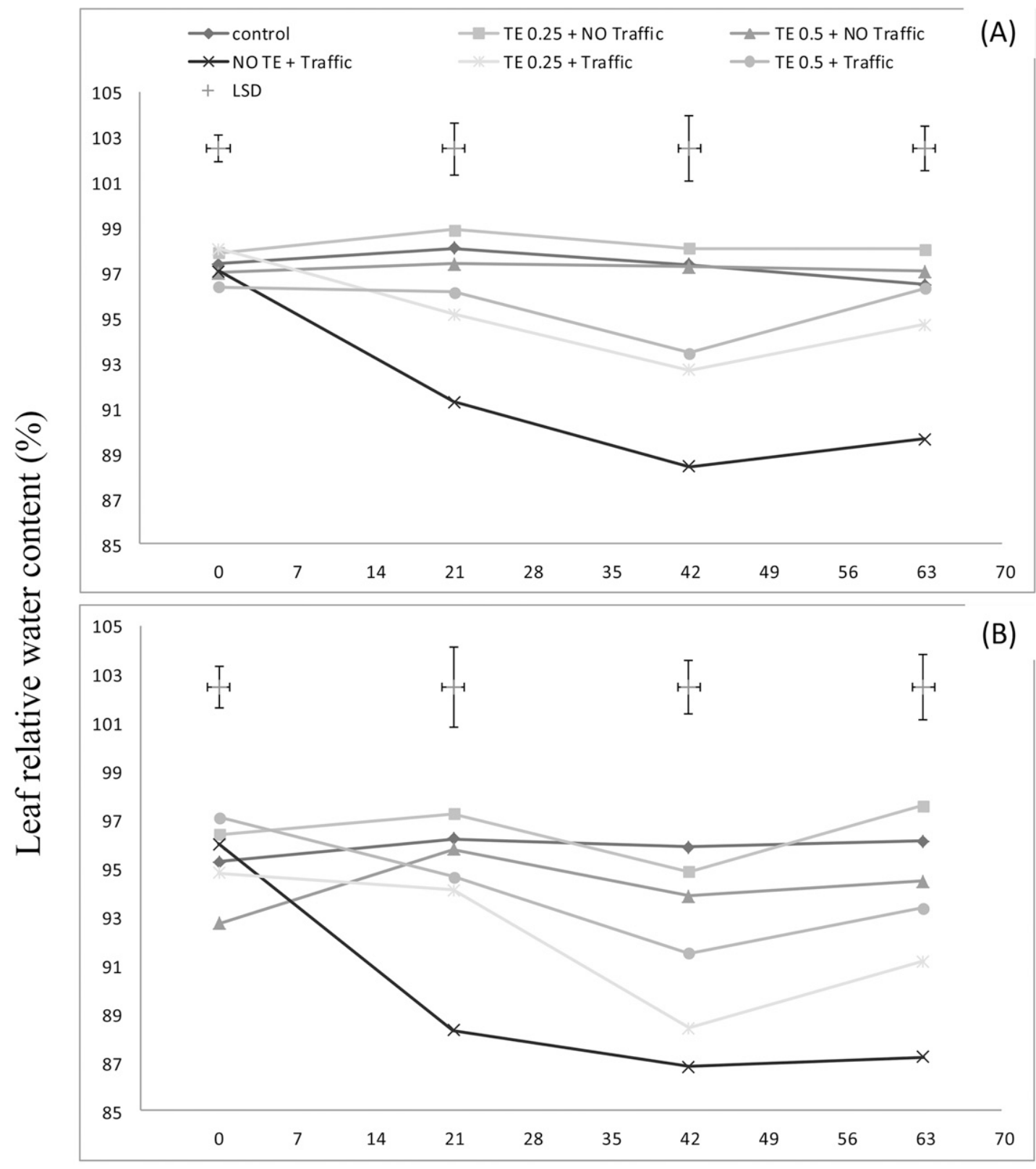

\section{Days of Treatments}

Fig. 1. Leaf relative water content of (A) tall fescue and (B) wheatgrass in response to traffic stress and trinexapac-ethyl. Bars indicate protected least significant difference $(P=0.05)$ for treatment comparisons at given days of treatment. 
calculated. The relative EL was calculated as $100 \times \mathrm{Ci} / \mathrm{Cmax}$ (Blum and Ebercon, 1981).

Chlorophyll extraction and concentration determination. One hundred milligram samples of leaf tissues were taken from each plot, cut with sterilized razor blade into small $(<1$ $\mathrm{mm}$ ) pieces, and located in a test tube containing $5 \mathrm{~mL}$ dimethyl sulfoxide (Hiscox and Israelstam, 1979). The tubes were placed in a $65^{\circ} \mathrm{C}$ water bath for $4 \mathrm{~h}$ (Kane and Smiley, 1983). Once cooled, $1 \mathrm{~mL}$ of the supernatant was placed in a cuvette and its absorbance was measured at 645 and $663 \mathrm{~nm}$ with a spectrophotometer (Spectronic Instruments, Rochester, NY). The concentration of chlorophyll $\left(\mathrm{mg} \cdot \mathrm{g}^{-1}\right.$ fresh weight) was calculated using Arnon (1949) equations.
Determinations of enzyme activities. Fresh leaves $(0.5 \mathrm{~g})$ were ground with a mortar and pestle in $5 \mathrm{~mL}$ of $50 \mathrm{~mm}$ phosphate buffer $(\mathrm{pH}$ $7.8)$ at $4{ }^{\circ} \mathrm{C}$. The homogenate was centrifuged at $13,000 g_{\mathrm{n}}$ for $15 \mathrm{~min}$. The supernatant was recovered to determine SOD and CAT activities as described previously (Chen et al., 2009).

Leaf catalase (CAT) activity. The 3-mL reaction solution contained $15 \mathrm{mM} \mathrm{H}_{2} \mathrm{O}_{2}$, $50 \mathrm{~mm}$ phosphate buffer ( $\mathrm{pH} 7.0$ ), and 50 $\mu \mathrm{L}$ of the enzyme extract. The reaction was initiated by adding the enzyme extracts, and the decreased absorbance of $\mathrm{H}_{2} \mathrm{O}_{2}$ (extinction coefficient $0.0394 \mathrm{~mm} \cdot \mathrm{cm}^{-1}$ ) within $1 \mathrm{~min}$ at $240 \mathrm{~nm}$ was recorded. One unit of CAT activity was defined as the amount of enzyme required for catalyzing the conversion of
$1 \mathrm{mmol} \mathrm{H}_{2} \mathrm{O}_{2}$ into water per minute (Chen et al., 2009).

Leaf SOD activity. The 3-mL reaction solution contained $13 \mathrm{~mm}$ methionine, $63 \mathrm{~mm}$ r-nitro blue tetrazolium chloride (NBT), $1.3 \mathrm{~mm}$ riboflavin, $50 \mathrm{~mm}$ phosphate buffer ( $\mathrm{pH} 7.8$ ), and $50 \mathrm{~mL}$ of the enzyme extract. The reaction solution was incubated for 10 min under fluorescent light $\left(80 \mu \mathrm{mol} \cdot \mathrm{m}^{-2} \cdot \mathrm{s}^{-1}\right)$. The absorbance was determined at $560 \mathrm{~nm}$ using a spectrophotometer (model M36; Beckman, CA). One unit of SOD activity was defined as the amount of enzyme required to inhibit the photochemical reduction of NBT by $50 \%$ (Chen et al., 2009).

Leaf APX activity. Leaf samples $(0.5 \mathrm{~g})$ were ground in $3 \mathrm{~mL}$ of extraction solution
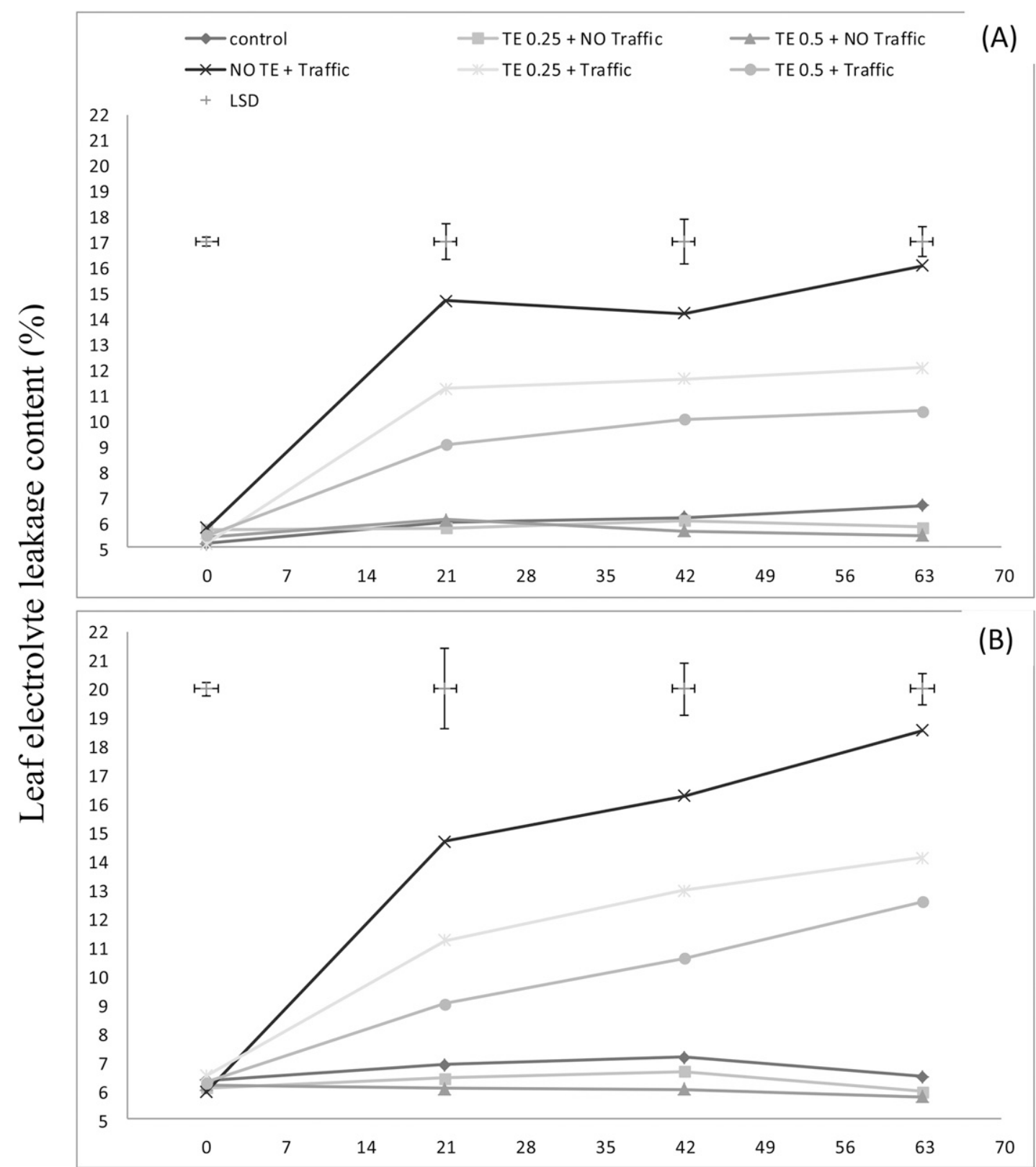

\section{Days of Treatments}

Fig. 2. Leaf electrolyte leakage content of (A) tall fescue and (B) wheatgrass in response to traffic stress and trinexapac-ethyl. Bars indicate protected least significant difference $(P=0.05)$ for treatment comparisons at given days of treatment. 
containing $50 \mathrm{~mm}$ phosphate buffer ( $\mathrm{pH} 7.0$ ), $2 \mathrm{~mm}$ ascorbate (AsA), and $5 \mathrm{~mm}$ ethylenediaminetetraacetic acid (EDTA) using a mortar and pestle at $4{ }^{\circ} \mathrm{C}$. The suspension was centrifuged
(Millipore Corporation, Billerica, MA) for $15 \mathrm{~min}$ at $13,000 \mathrm{~g}_{\mathrm{n}}$. The supernatants were used to analyze the enzyme activity. The $3-\mathrm{mL}$ reaction solution of APX contained $50 \mathrm{~mm}$ phosphate buffer ( $\mathrm{pH} 7.0), 0.5 \mathrm{~mm}$ AsA, $0.1 \mathrm{~mm}$ $\mathrm{H}_{2} \mathrm{O}_{2}$, and $0.1 \mathrm{~mL}$ of enzyme extracts. The APX activity was calculated following the decrease in the absorbance of AsA (extinction

Table 2. Leaf chlorophyll $\mathrm{a}, \mathrm{b}$, and $\mathrm{a}+\mathrm{b}$ contents affected by traffic stress and TE for wheatgrass and tall fescue.

\begin{tabular}{|c|c|c|c|c|c|c|c|}
\hline \multirow[b]{2}{*}{ Grass } & \multirow[b]{2}{*}{ TE } & \multicolumn{2}{|c|}{ Chl a (mg.g ${ }^{-1}$ dry wt) } & \multicolumn{2}{|c|}{ Chl b (mg.g ${ }^{-1}$ dry wt) } & \multicolumn{2}{|c|}{ Chl a + b (mg. ${ }^{-1}$ dry wt) } \\
\hline & & Traffic & No traffic & Traffic & No traffic & Traffic & No traffic \\
\hline \multirow[t]{3}{*}{ Wheatgrass } & No TE & $1.77 \mathrm{~b}^{\mathrm{z}}$ & $2.09 \mathrm{~b}$ & $0.57 \mathrm{a}$ & $0.58 \mathrm{~b}$ & $2.34 \mathrm{~b}$ & $2.67 \mathrm{~b}$ \\
\hline & TE 0.25 & $1.88 \mathrm{ab}$ & $2.17 \mathrm{a}$ & $0.61 \mathrm{a}$ & $0.64 \mathrm{ab}$ & $2.49 \mathrm{ab}$ & $2.82 \mathrm{a}$ \\
\hline & LSD $(0.05)$ & 0.14 & 0.14 & 0.09 & 0.09 & 0.16 & 0.13 \\
\hline \multirow[t]{3}{*}{ Tall fescue } & No TE & $1.58 \mathrm{~b}$ & $1.87 \mathrm{~b}$ & $0.49 \mathrm{a}$ & $0.50 \mathrm{~b}$ & $2.07 \mathrm{~b}$ & $2.37 \mathrm{c}$ \\
\hline & TE 0.25 & $1.71 \mathrm{a}$ & $1.93 \mathrm{~b}$ & $0.52 \mathrm{a}$ & $0.60 \mathrm{a}$ & $2.24 \mathrm{a}$ & $2.53 \mathrm{~b}$ \\
\hline & TE 0.5 & $1.71 \mathrm{a}$ & $2.03 \mathrm{a}$ & $0.53 \mathrm{a}$ & $0.63 \mathrm{a}$ & $2.25 \mathrm{a}$ & $2.66 \mathrm{a}$ \\
\hline
\end{tabular}

$\mathrm{Chl}=$ Chlorophyll; $\mathrm{TE}=$ trinexapac-ethyl; $\mathrm{LSD}=$ least significant difference.

${ }^{\mathrm{z}}$ Means within a column followed by the same letters are not significantly different based on the LSD test at $P=0.05$.

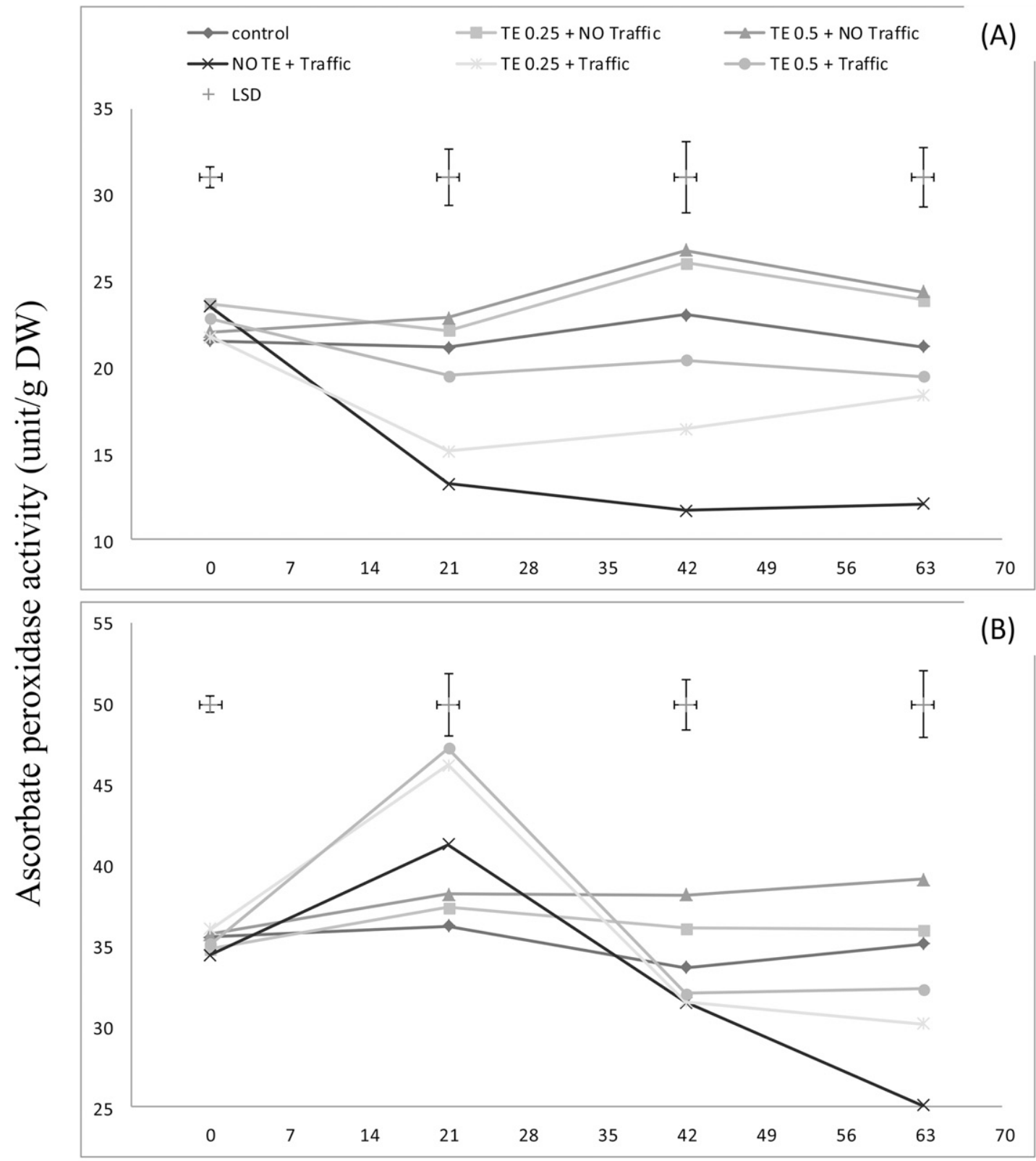

\section{Days of Treatments}

Fig. 3. Ascorbate peroxidase activities (A) tall fescue and (B) wheatgrass in response to traffic stress and trinexapac-ethyl. Bars indicate protected least significant difference $(P=0.05)$ for treatment comparisons at given days of treatment. 
coefficient $2.8 \mathrm{mM} \cdot \mathrm{cm}^{-1}$ ) within $1 \mathrm{~min}$ at 290 $\mathrm{nm}$. One unit of APX activity was defined as the amount of enzyme required to catalyze the oxidation of $1 \mathrm{mmol}$ AsA per minute (Chen et al., 2009).

Leaf POD activity. The peroxide activity was calculated by measuring the increase in absorbance at $470 \mathrm{~nm}$. The leaf samples (300 $\mathrm{mg}$ ) were ground with a pestle in an ice-cold mortar in $4 \mathrm{~mL}$ of $50 \mathrm{~mm}$ sodium phosphate buffer ( $\mathrm{pH}$ 7.0) containing 0.2 mM EDTA and $1 \%(\mathrm{w} / \mathrm{v})$ polyvinylpyrrolidone. The suspension was filtered through four layers of cheesecloth and then centrifuged at $4{ }^{\circ} \mathrm{C}$ for $30 \mathrm{~min}$ at $12,000 g_{\mathrm{n}}$. The supernatant $(0.8 \mathrm{~mL})$ was collected and used for the POD assay. The assay contained $50 \mu \mathrm{L}$ of $20 \mathrm{~mm}$ guaiacol, $2.83 \mathrm{~mL}$ of $10 \mathrm{~mm}$ phosphate buffer ( $\mathrm{pH} 7.0)$, and $50 \mu \mathrm{L}$ of enzyme extract. The reaction was started with $20 \mu \mathrm{L}$ of $40 \mathrm{~mm} \mathrm{H}_{2} \mathrm{O}_{2}$. The oxidation of guaiacol was measured by following the increase in absorbance at $470 \mathrm{~nm}$ for $2 \mathrm{~min}$. One unit of POD was defined as the amount of enzyme that caused a 0.01 increase in the absorbance at $470 \mathrm{~nm} / \mathrm{min}$ at the assay conditions (Han et al., 2008).

Soluble sugar content. Twenty milligrams of dry leaves powders was extracted four times for $15 \mathrm{~min}$ with $90 \%(\mathrm{v} / \mathrm{v})$ ethanol $(20 \mathrm{~mL})$. After centrifugation at $3000 g_{\mathrm{n}}$ for $10 \mathrm{~min}$, supernatants were collected and merged, and the ultimate volume was set to $40 \mathrm{~mL}$. Two milliliters of supernatant was collected and transferred into glass tube. Finally1 $\mathrm{mL}$ of phenol solution $(18 \%)$ and $5 \mathrm{~mL}$ of concentrated sulfuric acid were added. The mixture was shaken well, and absorption was read at $490 \mathrm{~nm}$ employing the mentioned spectrophotometer (Buysse and Merckx, 1993).

MDA content. A $0.2 \mathrm{~g}$ sample of fresh leaves was homogenized in $1.5 \mathrm{~mL}$ of $5 \%$ trichloroacetic acid and the remaining was deleted by centrifugation at $14,000 g_{n}$ for $25 \mathrm{~min}$. A $0.5 \mathrm{~mL}$ aliquot of supernatant was mixed with $1 \mathrm{~mL}$ of $20 \%$ trichloroacetic acid including $0.5 \%$ thiobarbituric acid. The mixture was warmed at $100{ }^{\circ} \mathrm{C}$ for $30 \mathrm{~min}$, rapidly cooled, and then centrifuged at 10,000 $g_{\mathrm{n}}$ for $10 \mathrm{~min}$. The supernatant was collected and its absorbance was read at 532 and 600 nm. Subtracting the nonspecific absorbance $(600 \mathrm{~nm})$, the concentration of MDA was determined with an extinction coefficient of $155 \mathrm{~mm}^{-1} \cdot \mathrm{cm}^{-1}$ (Heath and Parker, 1968).

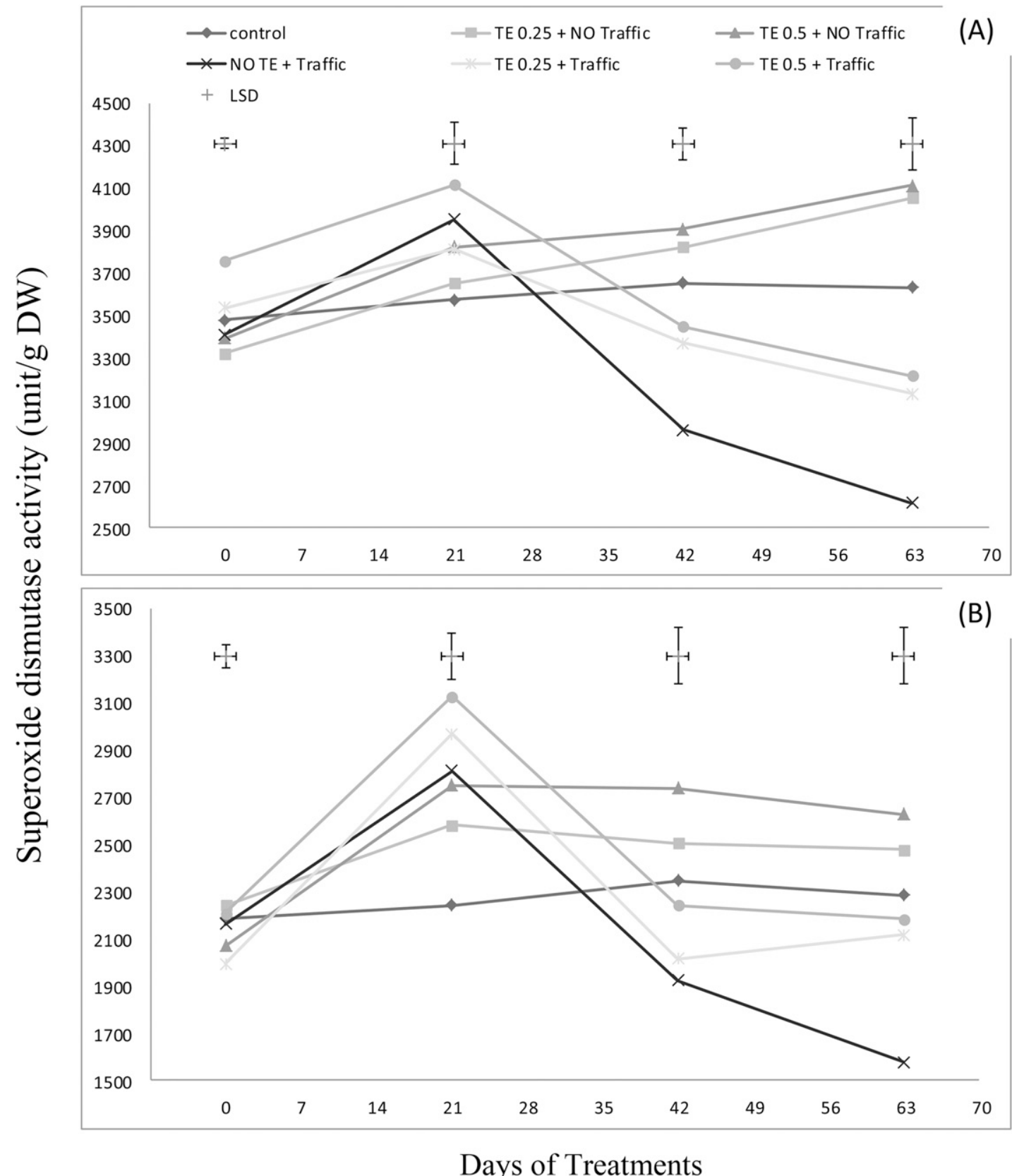

Fig. 4. Superoxide dismutase activities of $(\mathbf{A})$ tall fescue and $(\mathbf{B})$ wheatgrass in response to traffic stress and trinexapac-ethyl. Bars indicate protected least significant difference $(P=0.05)$ for treatment comparisons at given days of treatment. 
Experimental design and data analysis. The experiment was repeated for 2 years, and all of the measurements were taken four times per year. Because the data did not significantly differ between the first and 2nd years, the data from the sampling dates of these 2 years were pooled, and the averages were used for the statistical analysis to compare the species and the levels of the TE and traffic stress. The data were analyzed using Proc analysis of variance and differences among means were determined with a Fisher's protected least significant difference test at a $5 \%$ probability level using SAS (SAS, 2004).

\section{Result and Discussion}

Turf quality. Traffic stress decreased the turf quality in both grass species compared with the control plants (Table 1). TE application improved turf quality in the both species (Table 1). Tall fescue and wheatgrass showed $15 \%$ and $10 \%$ quality increase by $0.5 \mathrm{~kg} \cdot \mathrm{ha}^{-1} \mathrm{TE}$ treatment compared with the control plants, respectively. By improving the turf quality under traffic stress condition, TE compensated the negative effect of stress on turf quality (Table 1).

Similar positive effects of TE on the turf quality under simulated traffic conditions have been concluded by Williams et al. (2010). McCann and Huang (2007) reported that increases in the turf quality in response to TE treatment might occur as a result of the improved canopy photosynthesis capacity and single-leaf photochemical efficiency. In previous research, Samaranayake et al. (2008) reported that traffic stress decreased the turfgrass quality of creeping bentgrass (Agrostis stolonifera L.). Also, Minner and Valverde (2005) reported that a decreased shoot density and color under traffic stress reduced the turfgrass quality. The impact of TE application on turf quality has been evaluated by other researches (Roohollahi et al., 2010). McCann and Huang (2007) reported that increases in the turf quality in response to TE treatment might occur as a result of the improved canopy photosynthesis capacity and single-leaf photochemical efficiency.

Leaf $R W C$. The first day following TE and traffic application, the RWC of all plants was not substantially different (Fig. 1). After 21 d, however, the RWC of both species reduced under traffic stress condition. TE application significantly increased leaf RWC under traffic

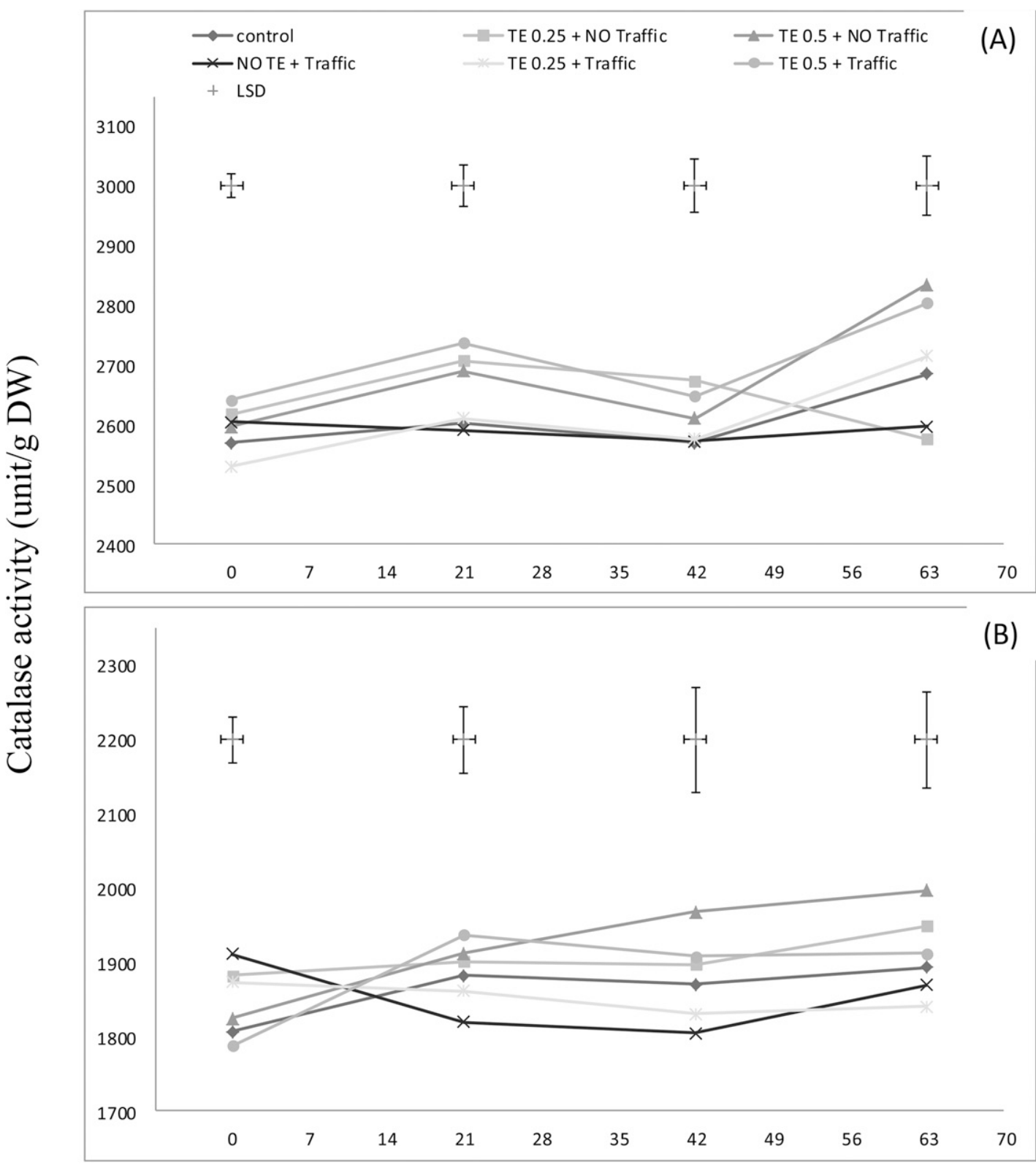

\section{Days of Treatments}

Fig. 5. Catalase activities of (A) Tall Fescue and (B) Wheatgrass in response to traffic stress and Trinexapac-ethyl. Bars indicate protected-least significant difference $(P=0.05)$ for treatment comparisons at given days of treatment. 
stress condition, whereas it had no positive effect in the absence of traffic stress. For wheatgrass, higher concentration $\left(0.5 \mathrm{~kg} \cdot \mathrm{ha}^{-1}\right)$ of TE was more effective in enhancing RWC as compared with $0.25 \mathrm{~kg} \cdot \mathrm{ha}^{-1}$ concentration. But for tall fescue, there was no significant difference among the three applied TE levels.

Traffic stress harms the leaves, stems, and crowns by compacting them horizontally and vertically which in turn may result in leaf RWC loss (Beard, 2005). Moreover, the RWC loss may be due to the increased evapotranspiration rate and reduced water absorption in response to soil compaction (Han et al., 2008). Decreased RWC under traffic stress condition has been reported for three turf species including Poa pratensis, F. arundinacea, and Zoysia japonica (Han et al., 2008). TE application may increase leaf water content by decreasing leaf growth rate and evapotranspiration rate, or by improving osmotic adjustments (Ervin and Koski, 2001; McCann and Huang, 2007). Xu and Huang (2011) have shown the effect of TE on increasing leaf RWC under drought stresses.

Electrolyte leakage. Traffic stress significantly increased the EL of tall fescue and wheatgrass throughout the experiment (Fig. 2). Under traffic stress condition, the species treated with TE displayed lower EL (Fig. 2). Application of TE at $0.5 \mathrm{~kg} \cdot \mathrm{ha}^{-1}$ concentration was the most effective treatment for decreasing the EL.

The first plant component affected by stress is the cell membrane (McCann and Huang, 2007). Whitlow et al. (1992) reported that EL was a sign of cell membrane deterioration in response to stress. It has been reported that heavy traffic stress on kentucky bluegrass, tall fescue, and japanese zoysia grass increased the EL by $\approx 151 \%, 196 \%$, and $178 \%$, respectively (Han et al., 2008). Traffic stress results in oxidative stress by producing reactive oxygen species (ROS) (Han et al., 2008). These compounds interrupt the normal cell metabolism by damaging lipids, proteins, and amino acids (McCann and Huang, 2007), which results in a loss of membrane integrity and intensifies the EL. TE application reduced EL in kentucky bluegrass under drought stress (Xu and Huang, 2011). By inducing resistance in the cell membrane of creeping bentgrass (Agrostis palustris), TE reduced the EL in response to combined drought and heat stresses

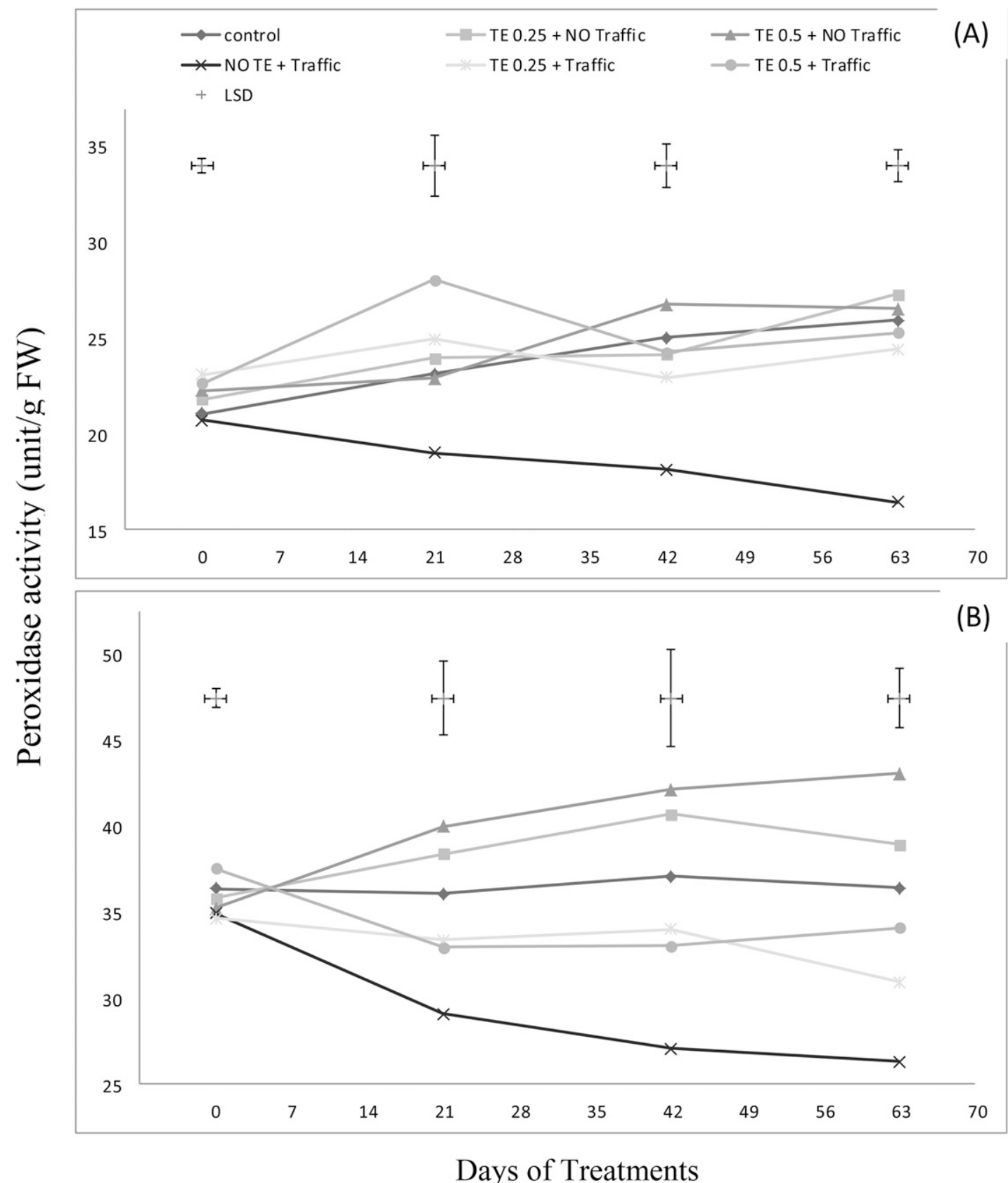

Fig. 6. Peroxidase activities of (A) tall fescue and (B) wheatgrass in response to traffic stress and trinexapac-ethyl. Bars indicate protected least significant difference $(P=0.05)$ for treatment comparisons at given days of treatment. 
(McCann and Huang, 2007). This reduction likely results from reducing the damage to the membrane induced by stress in response to TE treatment (Xu and Huang, 2011).

Chlorophyll content. The application of TE increased the chlorophyll a, b, and $\mathrm{a}+\mathrm{b}$ contents in both species under stress and nonstress conditions (Table 2). Traffic stress slightly reduced the chlorophyll a and $\mathrm{a}+\mathrm{b}$ contents in both species but it had no impact on chlorophyll $b$ content of studied species (Table 2). Irrespective to traffic stress treatment and species application of TE increased the chlorophyll $\mathrm{a}$, and $\mathrm{a}+\mathrm{b}$ contents (Table 2 ), which indicates that TE may neutralize the negative impact of traffic on chlorophyll content. In previous research, traffic stress resulted in chlorophyll $\mathrm{a}$ and $\mathrm{a}+\mathrm{b}$ loss in three species, kentucky bluegrass, tall fescue, and japanese zoysia grass, whereas it had no effect on chlorophyll $b$ content of all species. The damage rates positively correlated with the traffic stress level (Han et al., 2008). Oxidative damage has been proposed to reduce the chlorophyll content (Han et al., 2008), such that accumulation of free radicals during stress may be responsible for the loss of chlorophyll content (Inze and Montagu, 2002). Several investigators have demonstrated that TE treatment increases the chlorophyll content (Ervin and Koski, 2001; Fan et al., 2009). TE has been documented to reduce cell elongation by inhibiting gibberellin synthesis and increase the number of mesophyll cells, cytokinin content, and subsequently the chlorophyll concentration in leaves (Fan et al., 2009).

Antioxidant enzyme activity. The APX activity increased in wheatgrass and decreased in tall fescue grass $21 \mathrm{~d}$ after the application of traffic stress (Fig. 3). As the imposed traffic stress continued on days 42 and 63, the APX activity decreased in both species compared with control plants. Under nonstress conditions, TE-treated plants showed slightly enhanced APX activity. Under stress condition, TE application significantly improved the APX activity in tall fescue and there was no significant difference between the two applied TE levels by the end of the experiment (Fig. 3). For wheatgrass, both TE concentrations improved the APX activity of stressed-exposed plants on

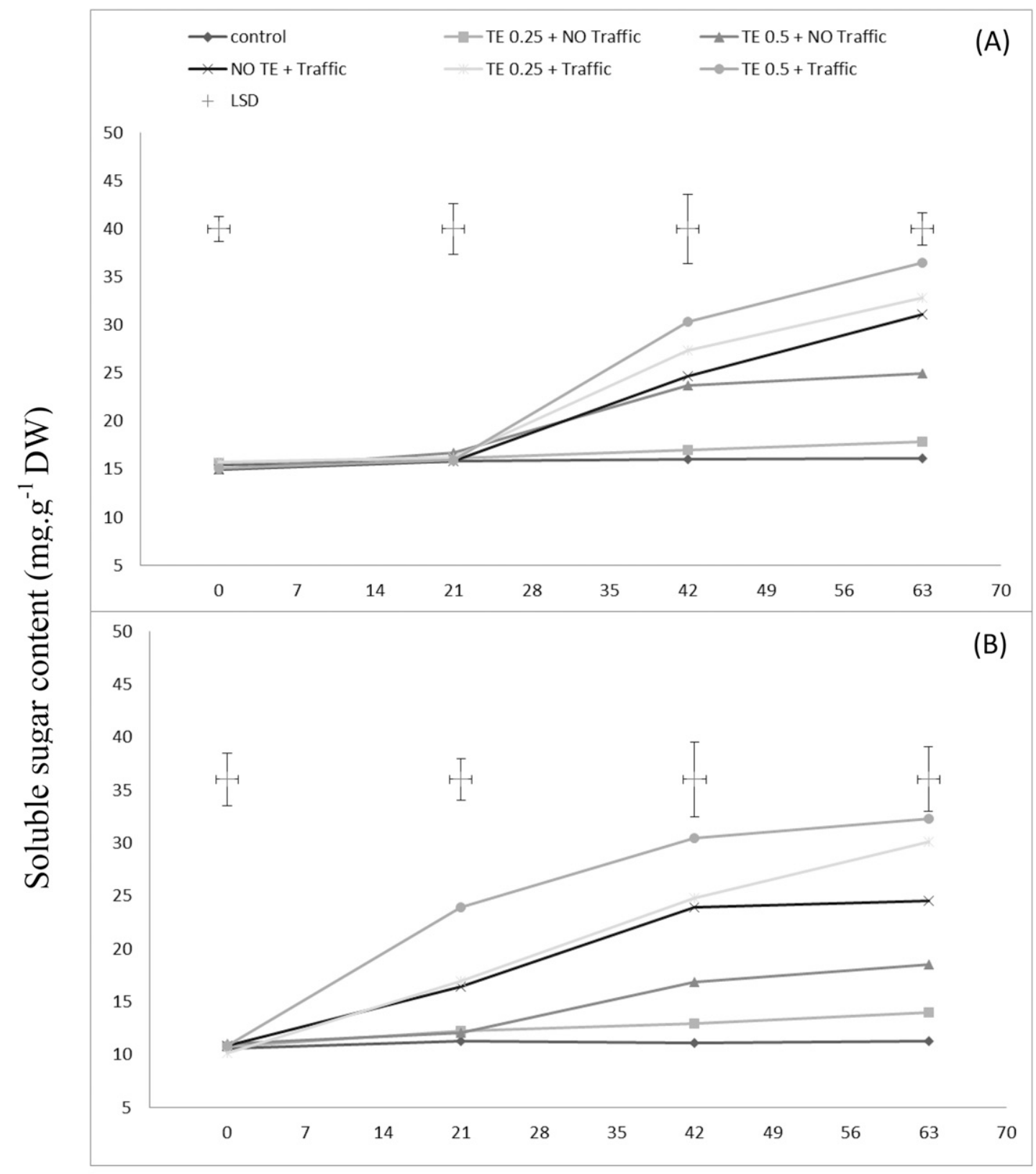

\section{Days of Treatments}

Fig. 7. Soluble sugar content of (A) tall fescue and (B) wheatgrass in response to traffic stress and trinexapac-ethyl. Bars indicate protected least significant difference $(P=0.05)$ for treatment comparisons at given days of treatment. 
days 21 and 63 so that the final APX activity of grass treated with $0.5 \mathrm{~kg} \cdot \mathrm{ha}^{-1}$ of TE was $30 \%$ higher than their nontreated counterparts (Fig. 3).

In both species, traffic stress increased SOD activity during the $21 \mathrm{~d}$ following stress treatment (Fig. 4). Thereafter, a decreasing trend was observed in enzyme activity of stressexposed plants as compared with the controls. Under nontraffic stress condition, TE application increased SOD activity of both grasses at each time of measurements. Under stress condition, TE application was effective in increasing SOD activity of wheatgrass throughout the experiment. For tall fescue, however, positive impact of TE was observed mostly from the third date of measurement (42 d following treatment application).
Traffic stress had no significant impact on CAT activity of both species as compared with the controls (Fig. 5). TE application at $0.5 \mathrm{~kg} \cdot \mathrm{ha}^{-1}$ concentration slightly increased CAT activity of both grasses under stress and unstress conditions.

On day 21, traffic stress increased the SOD activity but, on days 42 and 63, the SOD activities of both species showed a decreasing trend (Fig. 4). TE did not affect the SOD activity of tall fescue grass on day 21 , but improved the SOD activity on days 42 and 63 under traffic stress. On day 63, the SOD activity in nonstressed tall fescues increased in response to TE application. In wheatgrass, $0.5 \mathrm{~kg} \cdot \mathrm{ha}^{-1}$ TE improved the SOD activity under stress and nonstress conditions 21 and $42 \mathrm{~d}$ after treatment. Subsequently, both TE concentrations increased the SOD activity on day 63.

Under traffic stress, CAT activity was decreased on days 21 and 42 in wheatgrass. In wheatgrass and tall fescue, application of TE at $0.5 \mathrm{~kg} \cdot \mathrm{ha}^{-1}$ improved CAT activity on days 21,42 , and 63 under simultaneous traffic treatment (Fig. 5).

Traffic stress decreased the POD activity during the experimental period in the both studied species (Fig. 6). TE application did not change POD activity in tall fescue under nontraffic stress condition. For wheatgrass, however, TE at $0.5 \mathrm{~kg} \cdot \mathrm{ha}^{-1}$ concentration improved POD activity. On day 21, TE did not impact the POD enzyme activity, but enhanced it in wheatgrass on days 42 and 63 under nonstressed conditions (Fig. 6). During traffic stress, both

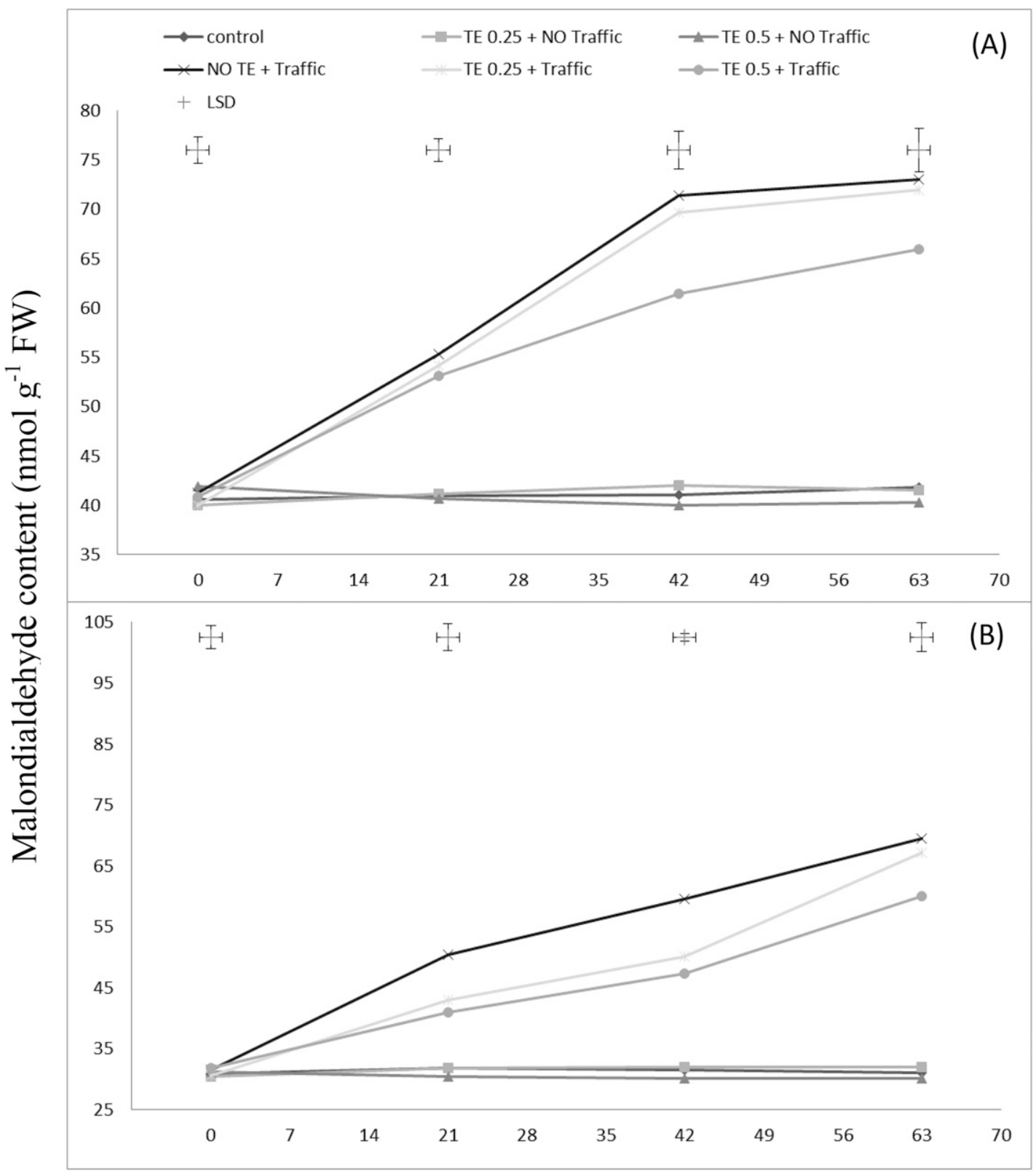

\section{Days of Treatments}

Fig. 8. Malondialdehyde content of (A) tall fescue and (B) wheatgrass in response to traffic stress and trinexapac-ethyl. Bars indicate protected-least significant difference $(P=0.05)$ for treatment comparisons at given days of treatment. 
TE concentrations improved the POD activity on days 21,42 , and 63 in fescue grass and on days 42 and 63 in wheatgrass in all measured dates (Fig. 6).

The results showed that the enhanced antioxidant due to TE treatment improved the traffic stress resistance in wheatgrass and tall fescue grass. SOD is known as one of the most powerful plant antioxidants to cope with ROS, which allows plants to resist stresses (Blokhina et al., 2003; Sarvajeet and Narendra, 2010). Zhang and Schmidt (2000) reported that the SOD activity in creeping bentgrass improved in response to TE treatment. Catalase can directly transform hydrogen peroxide into water and oxygen and subsequently completely remove this radical oxygen species (Sarvajeet and Nerendra, 2010). In kentucky bluegrass, the increased CAT concentration in response to $\mathrm{TE}$ improved the drought stress resistance $(\mathrm{Xu}$ and Huang, 2011). TE enhanced the kentucky bluegrass tolerance to salinity stress by improving the activity of the enzymes CAT, APX, POX, and SOD (Arghavani et al., 2012). In addition, TE induced shade-stress tolerance in creeping bentgrass by promoting the SOD enzyme activity (Ervin et al., 2004). Light traffic stress enhanced the POD activity of tall fescue and japanese zoysia grass, whereas it weakened the POD activity of kentucky bluegrass. Notably, the POD activity rate of all three species decreased in response to heavy and moderate traffic stress. As such, POD bestowed a higher traffic resistance because it minimizes $\mathrm{H}_{2} \mathrm{O}_{2}$ and prevents wall stiffening, which enhances the tolerance of leaves to abrasive forces (Han et al., 2008). To the best of our knowledge, significant investigations on the effects of traffic stress on the activities of other enzymes and the mechanisms by which TE impacts antioxidant enzymes have not been carried out.

Soluble sugar content. According to the results of the present study, the application of TE $\left(0.5 \mathrm{~kg} \cdot \mathrm{ha}^{-1}\right)$ increased the SSC content on days 42 and 63 , in both species under unstress conditions (Fig. 7). Traffic stress increased the SSC content on days 21 and 42 in wheatgrass and on days 42 and 63 in tall fescue compared with the control plants (Fig. 7). Under traffic stress, TE $\left(0.5 \mathrm{~kg} \cdot \mathrm{ha}^{-1}\right)$ increased the SSC content on days 21, 42, and 63 in wheatgrass, and on days 42 and 63 in tall fescue. In the present study, SSC content improved by TE $\left(0.5 \mathrm{~kg} \cdot \mathrm{ha}^{-1}\right)$ treatment during stress and unstress conditions (Fig. 7). Bian et al. (2009) concluded that TE increased SSC content in creeping bentgrass (A. stolonifera) under stress. The accumulation of SSC content has been associated with the plant ability to tolerate stresses and assists in recuperation following stress damage (Pessarakli, 2008).

Malondialdehyde. Traffic stress increased the MDA content on days 21,42 , and 63 in wheatgrass and on days 21 and 42 in tall fescue compared with the control plants (Fig. 8). During traffic stress, TE $\left(0.25 \mathrm{~kg} \cdot \mathrm{ha}^{-1}\right)$ decreased the MDA content on days 21 and 42 in wheatgrass (Fig. 8). TE $\left(0.5 \mathrm{~kg} \cdot \mathrm{ha}^{-1}\right)$ decreased the MDA content on days 21,42 , and 63 in wheatgrass, and on days 42 and 63 in tall fescue (Fig. 8). Results showed that traffic stress led to enhanced MDA content in tall fescue and wheatgrass. TE treated in both species exhibited lower MDA content than untreated counterparts. Free oxygen radicals damage has been proposed to increase the MDA content (Chen et al., 2009). An increase in MDA content, a product of membrane permeability and lipid peroxidation, is an index of oxidative damage to cell membranes under stress conditions such that accumulation of free radicals during stress can damage the membrane lipid (Guo et al., 2005). Arghavani et al. (2012) reported that TE application decreased MDA content during salt stress in kentucky bluegrass. Decrease in the MDA content in response to TE treatment might be a result of the increased antioxidant enzyme activities and increased plant protection against oxidative damage (Arghavani et al., 2012; Yang et al., 2012).

\section{Conclusions}

Based on our results, we can conclude that the application of TE at $0.5 \mathrm{~kg} \cdot \mathrm{ha}^{-1}$ enhanced the traffic resistance of both species. TE application likely decreased the lawn damage induced by traffic stress by improving the turf quality, chlorophyll concentration, leaf water content, SSC content, and antioxidant activity while reducing the EL and MDA content. The enhanced enzyme activity of APX, POD, and SOD likely effectively induced traffic stress resistance.

\section{Literature Cited}

Adams, R., E. Kerber, K. Pfister and E.W. Weiler. 1992. Studies on the action of the new growth retardant CGA 163'935 (cimectacarb). Plant Growth Regulation 818-827.

Arghavani, M., M. Kafi, M. Babalar, R. Naderi, M.A. Hoque, and Y. Murata. 2012. Improvement of salt tolerance in Kentucky bluegrass by trinexapac-ethyl. HortScience 47:1163-1170.

Arnon, D.I. 1949. Copper enzyme in isolated chloroplasts. Plant Physiol. 25:1-5.

Baldwin, C.M., H. Liu, L.B. McCarty, W.L. Bauerle, and J.E. Toler. 2006. Effects of trinexapac-ethyl on the salinity tolerance of two bermudagrass cultivars. HortScience 41:808-814.

Barrs, H.D. and P.E. Weatherley. 1962. A reexamination of the relative turgidity techniques for estimating water deficits in leaves. Austral. J. Biol. Sci. 15:413-428.

Beard, J.B. 2005. Turfgrass Management for Golf Courses. Ann Arbor Press, Chelsea, MI.

Bian, X., E. Merewitz, and B. Huang. 2009. Effects of trinexapac-ethyl on drought responses in creeping bentgrass associated with water use and osmotic adjustment. J. Amer. Soc. Hort. Sci. 134:505-510.

Blokhina, O., E. Virolainen, and K.V. Fagerstedt. 2003. Antioxidants, oxidative damage and oxygen deprivation stress: A review. Ann. Bot. (Lond.) 91:179-194.

Blum, A. and A. Ebercon. 1981. Cell membrane stability as a measure of drought and heat tolerance in wheat. Crop Sci. 21:43-47.

Brosnan, J.T., A.W. Thoms, G.K. Breeden, and J.C. Sorochan. 2010. Effects of various plant growth regulators on the traffic tolerance of 'Riviera' Bermudagrass (Cynodon dactylon L.). HortScience 45:966-970.
Buysse, J. and R. Merckx. 1993. An improved colorimetric method to quantify sugar content of plant tissue. J. Expt Bot. 44:1627-1629.

Chen, C., S. Lu, Y. Chen, Z. Wang, Y. Niu, and Z. Guo. 2009. A gamma-ray induced dwarf mutant from seeded bermudagrass and its physiological responses to drought stress. HortScience 134:22-30.

Cockerham, S.T. and D.J. Brinkman. 1989. A simulator for cleated-shoe sports traffic on turfgrass research plots. Calif. Turfgrass Cult. 39:9-10.

Ervin, E.H. and A.J. Koski. 2001. Kentucky bluegrass growth responses to trinexapac-ethyl, traffic, and nitrogen. Crop Sci. 41:1871-1877.

Ervin, E.H., X.Z. Zhang, S.D. Askew, and J.M. Goatley. 2004. Trinexapac-ethyl, propiconazole, iron, and biostimulant effects on shaded creeping bentgrass. HortTechnology 14:500-506.

Fan, G., X. Bian, H. Li, Z. Menh, and S. Liu. 2009. Growth responses of Kentucky bluegrass (Poa pratensis $\mathrm{L}$.) to trinexapac-ethyl applied in spring and autumn. Front. Agric. China 3:186-189.

Goss, R.M., J.H. Baird, S.L. Kelm, and R.N Calhoun. 2002. Trinexapac-ethyl and nitrogen effects on creeping bentgrass grown under reduced light conditions. Crop Sci. 42:472-479.

Guo, Z., H. Tan, Z. Zhu, S. Lu, and B. Zhou. 2005. Effect of intermediates on ascorbic acid and oxalate biosynthesis of rice and in relation to its stress resistance. Plant Physiol. Biochem. 43:955-962.

Han, L.B., G.L. Song, and X. Zhang. 2008. Preliminary observation of physiological responses of three turfgrass species to traffic stress. HortTechnology 18:139-143.

Heath, R.L. and L. Parker. 1968. Photoperoxidation in isolated chloroplasts: I. Kinetics and stiochiometry of fatty acid peroxidation. Arch. Biochem. Biophys. 125:189-198.

Hiscox, J.D. and G.F. Israelstam. 1979. A method for the extraction of chlorophyll from leaf tissue without maceration. Can. J. Bot. 57:1332-1334.

Inze, D. and M.V. Montagu. 2002. Oxidative stress in plants. Taylor \& Francis, New York, NY.

Kane, R.T. and R.W. Smiley. 1983. Plant growth regulating effects of systemic fungicides applied to Kentucky bluegrass. Agron. J. 75:469-473.

McCann, S.E. and B. Huang. 2007. Effects of trinexapac-ethyl foliar application on creeping bentgrass responses to combined drought and heat stress. Crop Sci. 47:2121-2128.

McCullough, P.E., H. Liu, L.B. McCarty, T. Whitwell, and J.E. Toler. 2006. Bermudagrass putting green growth, color, and nutrient partitioning influenced by nitrogen and trinexapacethyl. Crop Sci. 46:1515-1525.

Michael, T.D. and D.W. Williams. 2010. Overseeding and trinexapac-ethyl effects on tolerance to simulated traffic of four bermudagrass cultivars grown as a sand-based athletic field. HortTechnology 20:724-729.

Minner, D.D. and F.J. Valverde. 2005. The effect of traffic intensity and periodicity on Poapratensis L. performance. Intl. Turfgrass Soc. Res. J. 10:387-392.

Pannacci, E., G. Covarelli, and F. Tei. 2004. Evaluation of trinexapac-ethyl for growth regulation of five cool-season turfgrass species. HortScience 661:349-351.

Pessarakli, M. 2008. Handbook of turfgrass management and physiology. CRC Press, Boca Raton, FL.

Roohollahi, I., M. Kafi, and R. Naderi. 2010. Drought reaction and rooting characteristics in response to plant growth regulators on Poa pratensis cv. Barimpala. J. Food Agr. Environ. 8:132-135.

Samaranayake, H., T.J. Lawson, and J.A. Murphy. 2008. Traffic stress effects on bentgrass putting 
green and fairway turf. Crop Sci. 48:11931202.

Sarvajeet, S.G. and T. Narendra. 2010. Reactive oxygen species and antioxidant machinery in a biotic stress tolerance in crop plants. Plant Physiol. Biochem. 3:1-22.

SAS. 2004. SAS 9.1.2 qualification tools user's guide. SAS Institute Inc., Cary, NC.

Whitlow, T.H., N.L. Bassuk, T.G. Ranney, and D.L. Reichert. 1992. An improved method for using electrolyte leakage to assess membrane competence in plant tissues. Plant Physiol. 98:198-205.

Williams, D.W., P.B. Burrus, and K.L. Cropper. 2010. Seeded bermudagrass tolerance to simulated athletic field traffic as affected by cultivars and trinexapac-ethyl. HortTechnology 20: 533-538.

Xu, C. and B. Huang. 2011. Proteins and metabolites regulated by trinexapac-ethyl in relation to drought tolerance in Kentucky bluegrass. J. Plant Growth Regul. 31:25-37.
Yang, Z., J. Yu, E. Merewitz, and B. Huang. 2012. Differential effects of abscisic add and Glycine Betaine on physiological responses to drought and salinity stress for two perennial grass species. J. Amer. Soc. Hort. Sci. 137: 96-106.

Zhang, X. and R.E. Schmidt. 2000. Application of trinexapac-ethyl and propiconazole enhances superoxide dismutase and photochemical activity in creeping bentgrass. HortScience 125 : $47-51$. 